\title{
Comparison of Labor Laws in China, Russia, and the US
}

\author{
Richard A. Posthuma \\ Department of Marketing and Management, College of Business Administration, University of Texas at El Paso, El Paso, \\ TX, USA \\ Email:rposthuma@utep.edu
}

How to cite this paper: Posthuma, R. A. (2020). Comparison of Labor Laws in China, Russia, and the US. Beijing Law Review, 11, 128-143.

https://doi.org/10.4236/blr.2020.111009

Received: January 7, 2020

Accepted: February 7, 2020

Published: February 10, 2020

Copyright (c) 2020 by author(s) and Scientific Research Publishing Inc. This work is licensed under the Creative Commons Attribution International License (CC BY 4.0).

http://creativecommons.org/licenses/by/4.0/

\begin{abstract}
This article compares labor laws in China, Russia, and the US. It demonstrates how mimetic isomorphic tendencies and general principles of fairness such as equality, equity, and need may have resulted in similarities in the labor laws across all 3 countries. However, it is also shown that unique cultural, social, and historical factors have created significant differences in these labor laws. Understanding these differences will inform policy makers and business leaders.
\end{abstract}

\section{Keywords}

Labor Laws, China, Russia, US Comparative Laws

\section{Why Study Comparative Labor Laws?}

The importance of comparing labor laws across different countries is based on two factors. The first reason is the ubiquity of the employment relationship across different countries. Local employers provide the majority of jobs in most countries. Yet the laws in each country are sometimes similar and sometimes very different. In addition, as Multinational Enterprises (MNEs) move into different countries, they often encounter labor laws different than in their home country (Dowling Jr., 2001). MNEs need to be able to understand, adapt, and adjust to the differences as they expand their operations and hire more local employees that are covered by different labor laws (Brown, 2012).

The second reason is the need for governments to regulate the relationship within their own borders. The study of comparative labor laws enables policy makers to be more informed about successful models of employment regulation in other countries (Lee, McCann, \& Messenger, 2007). 


\subsection{Research Problem and Objective}

Unfortunately, prior research has not sufficiently explicated the differences and similarities of labor laws in different countries. A potential problem with this is that MNEs may not adequately understand the laws of other countries. When this happens, they can be accused of violating the laws of the countries in which they operate. Recent reports suggest that this may have occurred with major MNEs operating in China (Brown, 2019). Therefore, it is important to carefully analyze the similarities and differences in labor laws in different countries so that MNEs will understand how to comply with foreign laws. The result will be an increase in international economic cooperation and growth. In addition, the study of comparative labor laws is needed so that governments can benefit from an understanding of how their labor laws compare to those of other countries.

Prior research has generally described the provisions of laws in single countries. For example, prior research has described the changes in China's labor law that took place in 2008 (Harper, 2009; Jing, 2009; Wang, 2009).

Other work has examined the differences between labor laws under the Soviet Union and more contemporary laws under the Russian Federation (Bliss, 1997); and also the application of international labor laws in Russia (Deak, 1995).

Nevertheless, what is clearly needed is a direct comparison of similar provisions of labor laws in different countries. That analysis is done in this article.

\subsection{Research Method and Approach}

Preparation of the analysis reported in this study began with discussions with practicing managers in China, Russia, and the US they were asked about the key labor laws in their own countries. Then, a review of the literature on the labor laws in China, Russia and the US was conducted. This review focused on the specific provisions of labor laws that are most common across countries and cultures (Pull, 2002). In addition, special attention was given to recent changes in the labor laws in these countries (e.g. Franceschini, 2020; Mahy, Mitchell, Sutherland et al., 2019). Information about the recent changes was confirmed by searching the online information available for law firms that practice labor laws in different countries (e.g., Isaacs, Lu, \& An, 2019). Then, a summary of the laws in these 3 countries was prepared. Comparing and contrasting the provisions across countries was an important goal of this method.

\subsection{Ubiquity of the Employment Relationship}

People work for employers all across the globe. It has been estimated that there are more than 3 billion people who are involved in an employment relationship (Torres, 2013). At the most fundamental level, this employment relationship is a two-party consensual exchange in which an employee agrees to provide labor in return for wages and benefits from their employer. In this way, the employee meets his or her interests in obtaining income, and the employer meets its interest in obtaining the services of the worker. So long as the employee and employ- 
er both see the relationship as being in their own self-interest, they will voluntarily engage with each other in the work-for-compensation transaction that is the essence of employment.

Not surprisingly, this symbiotic relationship is permitted and encouraged by governments in every country across the world. Not only does it provide benefits to both parties (employee and employer) but also provides benefits to other stakeholders. This includes the employee's family members who vicariously benefit from the economic rewards of the employee's labor (Garcia, Posthuma, \& Quinones, 2010). It also benefits the employer's stakeholders, such as its customers, who receive the products and services provided by the employer, owners who share the profits, and the communities where the employer provides jobs thereby enhancing general economic conditions.

Yet, the interests of employees and employers do not always converge. Employees want higher wages, better benefits, and better job security; but employers want lower costs, as well as more output and better quality of work from their employees. In some situations, there are asymmetrical advantages that can favor one party over the other. For example, where there are few jobs and many applicants for those jobs, employers could drive down wages, and provide work environments that are less desirable or less safe than they otherwise could be, thereby exploiting their workers.

In other situations, jobs are plentiful and workers are scarce. When this occurs, employees sometimes have the potential to engage in self-serving counterproductive behaviors that can be detrimental to their employers. This can include taking advantage of the employment relationship by quitting their job and going to work for a competitor, with very little notice, causing disruption to the employer's operations. In other circumstances employees could take important business knowledge with them as they leave, causing harm to their previous employer.

\subsection{Labor Laws in Different Countries}

Governments in every country have recognized the potential for exploitation that could harm workers, and also for employee counterproductive behaviors that could harm employers. In response they have adopted legal protections to prevent worker exploitation (Posthuma, Flores, Dworkin, \& Pavel, 2016), and protections for employers to restrict counterproductive employee behaviors (Posthuma, Dworkin, Torres, \& Bustillos, 2000). However, every country has adopted its own unique set of labor laws based on its own cultural and historical influences (Cooney, Gahan, \& Mitchell, 2011; Roehling, Posthuma, \& Hickox, 2008). Some laws are designed to require adequate working conditions and protect worker rights (Posthuma \& Ebert, 2011). Others are designed to prohibit discrimination against employees based on demographic differences (Cheng, Flores, Singh \& Posthuma, 2018; Tiefenbrun, 2017).

However, one thing is clear. The labor laws of one country generally do not 
apply in another country (Posthuma, Roehling, \& Campion, 2006). Thus, although the employment relationship is globally ubiquitous, the laws regulating that relationship are exclusive to each country. That is one reason that the labor laws of a country are often a reflection of the unique history and culture of that country. There are two implications of this wide variety of labor laws across the globe.

The first implication of the wide variety of labor laws is that it is important to understand the similarities across countries where they do exist. The identification of similarities enables broad conclusions and agreement about the fundamental principles that are globally applicable across countries.

The most important principle is that employment laws can promote fairness in the employment relationship. A commonly used model of justice suggests that there are three universally applicable criteria to assess fairness: equality, equity, and need (Rawls, 1971). Each of these three criteria can be used to explain how fairness in the employment relationship can be achieved through the adoption of certain types of labor laws.

The equality principle justifies laws that require all employees will receive the same outcome, as in Russia, where all employees receive a minimum of 28 days of paid vacation per year. This is an example of equality because all employees receive at least the same basic minimum.

The equity principle justifies laws that require employees to receive different outcomes based on some legitimate and objective criteria. For example, the equity principle explains the fairness of laws that require employees who have stayed working for the same employer should be rewarded with more vacation days, as they are in China. This is an example of equity because those who have remined loyal to the same company are rewarded with more vacation.

The need principle justifies laws that require better outcomes for employees who have greater needs. For example, Russian labor law provides special protections for pregnant women and nursing mothers. This helps to meet the special needs that they have as they give birth and raise children.

The second implication of the variety of labor laws across countries is the importance of specifying the differences in labor laws across countries. The identification of differences enables comparisons and contrasts that can identify alternative provisions for policy makers could consider adopting in their own countries. It can also suggest possible benefits that employers could provide to their workers even though they are not legally required to do so. However, they could voluntarily provide additional benefits in order to attract and retain a loyal workforce. A partial justification for providing the types of benefits that are identifying by comparing labor laws is that they different provisions have been perceived as important and legitimate in other countries.

For example, in the US there no generally applicable federal law that required paid family leave in the private sector. However, other countries such as China and the Russian Federation (hereinafter "Russia") do require this type of benefit. 
China provides 128 days of paid family leave (Jia, Dong, \& Song, 2018), and Russia provides 140 days of paid family leave (Addati, Cassirer, \& Gilchrist, 2014; IBP, 2016). By comparison even though the US does not generally require this form of paid leave, U.S, employers could voluntarily choose to adopt a policy that would, and many have done so.

Therefore, it is important to study labor laws in different countries. This paper compares labor laws in China, Russia, and the US. These countries were chosen because they each have a large workforce, have developed their labor laws for many years, continue to make changes in those laws (Gerasimova, Korshunova, \& Chernyaeva, 2017), and have significant similarities and differences in how they approach the regulation of the employment relationship.

\section{Similarities in the Structure and Sources of Labor Laws across Countries}

There are several general similarities in employment law provisions across different countries. Two of these similarities are the structure of labor laws and the sources of labor laws.

First, in each country there are country-wide federal laws, and also local laws with different standards. In China, Russia, and the US there are standardized federal labor laws that provide a certain level of protection to workers that are the same across the whole country (Demidov, 2019). However, each country also has labor laws that are somewhat different in political subdivisions within a country such as provinces, regions, states, or cities (Posthuma, 2012). It is also noteworthy that in each country the differences usually provide greater protections for workers at the local level than the protections available at the national level. Thus, each country has recognized the importance of balancing the needs for country-wide standardization, with the desire for local governments to provide some additional protections to workers in their region (Brown, 2010, 2012; Yang, 2017).

Second, in each country there are several similar sources of labor laws. These begin with the country' constitution; and then includes federal labor laws, proclamations from the chief executive of the country, decisions from courts, and regulations from administrative agencies that focus on particular topics such as equal employment opportunity, methods for payment of wages, safety, etc. (IBP, 2016; Yang, 2017; Sychenko, 2019).

Thus, despite the cultural and historical differences across countries, there is a degree of mimetic isomorphism in the methods whereby labor laws are created. Mimetic isomorphism is a theory that predicts that one organization will copy the structures that it sees another organization using when it believes that it has worked well for the other organization (Dimaggio \& Powell, 1983). Although this theory has been shown to explain why one company will copy the structures of another company, it may also explain why one country adopts the structural elements of labor laws used in another country. Moreover, these similarities can 
include similar provisions in labor laws themselves. For example, if a country sees that other countries have established minimum wage levels for the benefit of their workers, they could adopt them in their own country too. There are several examples of this in China, Russia, and the US.

\subsection{Similarities in Protections and Benefits for Workers}

Given the similarities of the structure and sources of labor laws in different countries it is not surprising that the historical influences that affect the adoption of regulatory environments in different countries have resulted in similar laws in China Russia, and the US (Cooney et al., 2011; Roehling et al., 2008). Moreover, each country has enacted several similar laws that meet the universally accepted principles of fairness of equality, equity, and need.

Minimum Wage: Each country has national provisions for a minimum wage level, with some differences at the local level within specific jurisdictions. Also, as time passes each country has raised the level of minimum wages. This is an example of the universality of the equality-based principle of fairness. All 3 countries recognize that employees should be paid at least some equal level of wages.

Overtime Pay: Also, each country requires that employees be paid at 1.5 tunes the regular rate of pay for overtime, or hours worked above a certain level. However, the eligibility for overtime pay varies across countries. In China overtime pay applies for hours worked over 8 per day or 40 per week (Boguen, 2019). In Russia and the US overtime pay applies for hours worked over 40 per week. This is an example of the universality of the equity-based principle of fairness. All 3 countries recognize that above a certain number of hours worked employees have earned the right to be paid a higher wage rate.

Social Insurance Payroll Taxes. In addition, each country also requires the payment of taxes based on the amount of wages that employees receive. These taxes are designed to fund programs for social insurance, retirement, etc. that workers may be entitled to receive at some point in their lives. This is an example of the need-based principle of fairness. All 3 countries recognize that employees will, at some time in their lives, e.g., at retirement, need some financial support that goes beyond the wages and benefits that their employer provides.

These are all interesting and important protections for workers. Most prior research tends to focus almost exclusively on the degree to which labor laws provide protections for workers. This is an important topic. However, since employment is a relationship between workers and employers it necessary to consider the impact of labor laws on employers as well. That is the focus of the following section (Wang, 2009).

\subsection{Similarities in Protections and Benefits for Employers}

There are also some similarities in the types of protections that employers are afforded against the possible counterproductive behaviors of workers. 
In all 3 countries, employers have the right to choose whom to hire, although this right has limitations. Also, in all 3 countries, employers can unilaterally end the employment relationship even without the consent of the employee. However, each country has very different restrictions on this right.

In the US the general rule is something called "employment-at-will". Under this general common law principle either the employee or the employee can end the employment relationship without the requirement of proving that they had a good and legal justification for doing so. However, there are several categories of employees that have greater protections, such as teachers who have tenure, employees who are covered by a collective bargaining agreement, government employees, etc. For those employees it is generally required that the employer be able to show that they have established rules, the employee knew about the rules, and that the employee violated the rules. This can be referred to as the requirement of having a "just cause" for employment termination. The labor laws in China and Russia do not follow the employment-at-will principle. Their laws are closer to the just cause requirement that applies to some employees in the US.

In China it is easier for employers to terminate an employee during their initial probationary period. After that, the employer may agree with the employee to establish a fixed term employment contract for a limited period of time, or for an open-ended contract with no fixed time limit (Boguen, 2019; Yang, 2017). Ending the employment relationship after the probationary period generally requires that the employer has established work rules, that the employee knew about the rules, and that the employee violated these rules.

Russia also has similar laws. These laws generally require the employer to prove that the employer has committed serious violations of work rules (Gerasimova, Korshunova, \& Chernyava, 2017; IBP, 2016).

In each country there are some protections for workers and some protections for employers. However, the labor laws provide more protections for employees than they do for employers. This difference is primarily the result of need-based fairness. Typically, employers have greater potential power in the employment relationship because they can replace employees with other people. This creates an asymmetrical power imbalance that favors employers over employees. Thus, employees have a greater need for protection in the employment relationship than do employers. This need is met by the governments in each country providing some protections for workers.

\subsection{Comparisons of Similarities across Countries}

The labor laws in different countries have similar structural foundations; and also the sources of those labor laws tend to be similar. The structural foundations include standardized laws across the whole country with adaptations in local political jurisdictions. The similarities also include a national constitution, federal labor laws, etc. This suggests that the mimetic isomorphism perspective may provide an explanatory rationale for how labor laws developed across the 
globe.

Yet, even within the similarities of structural foundations and sources of labor laws, there remain unique differences. For example, although all three countries include a minimum wage, and provisions to increase the minimum wage over time, the actual minimum wage levels are quite different in the different countries. This indicates that the pressures of mimetic isomorphism are at least somewhat constrained by other pressures such as the economic conditions in each country. This also suggests that even though the equality-based principle of treating all employees similarly may provide a justification for minimum wages, the equality that is provided is equal within their own country, and not equal to what is provided in other countries. Thus, the scope of the standard of comparison for equality fairness may be limited to the borders of each country.

Also, the substantive protections of some labor laws do show some consistencies. For example, all countries provide overtime pay, the provisions are similar in that they require overtime pay at 40 hours worked per week; but only China also requires overtime pay at 8 hours worked per day. This suggests that the equity-based principle of treating employees differently based on what they have earned based on the number of hours worked, has been enacted somewhat differently in different countries.

With respect to the similarities of protections and benefits for employers, these too may have been, in part, the result of mimetic isomorphism processes. As employers recognize the problems that can occur if they have difficulties in ending the employment of unproductive workers, it is logical that they would urge their government to provide them with some flexibility under their labor laws. However, despite some similarities across countries in this regard, there remain significant differences. By comparing China, Russia, and the US we can see that both China and Russia provide more protections for workers from unjust termination than is provided in the US. Although China and Russia go about it differently, they both provide a type of just cause standard that is not generally applicable in the US. It could be argued that the need-based type of fairness is more strongly supported by the provisions of laws in China and Russia, than in the US.

Thus, it can be observed that the mimetic isomorphism tendencies and generally accepted principles of fairness may explain many similarities across countries, but there remain significant differences.

\section{Differences in Labor Laws across Countries}

Despite the tendencies of these 3 countries to engage in isomorphic adoption of similar laws on some topics based on similar fundamental principles of fairness, there nevertheless remain significant differences as well.

\subsection{Differences in Protections and Benefits for Workers}

Holidays: All 3 countries have some form of recognition for the possibility of 
paid time off on certain designated holidays. China and Russia mandate that employees be paid for time off on certain holidays. However, the holidays are different in China and Russia. The US designates holidays but does not require pay for all workers on those days. In different countries, the designation of the specific days that are recognized as holidays is based on cultural, historical, and other factors. In this way, country labor laws use holidays to perpetuate the remembrance and continuation of these national priorities by giving employees time off from work.

The paid holidays in China are based primarily on social and cultural history. The paid holidays in China are: New Year's Day, Lunar New Year's Day (Called Chinese New Year or Spring Festival), Qing Ming Festival (Tomb-Sweeping Day), Labor Day (falls on the $1^{\text {st }}$ of May), Dragon Boat Festival, Mid-Autumn Festival, National Day (falls on the first day of October) (Yang, 2017).

The paid holidays in Russia are based in part on the same holidays that other countries use and in part based on the unique political history of Russia (IBP, 2016). The paid holidays in Russia are: New Year's Day (January 1), Christmas (January 7), International Women's Day (March 8), International Labor Day (May 1), Spring Day (May 2), World War II Victory Day (May 9), Independence Day (June 12), Revolution Day (November 7), and Constitution Day (December 12) (IBP, 2017).

The US federal government does designate certain holidays as national holidays, but it does not require that all employees receive paid time off for those days. Federal offices are closed and federal employees are paid. However, federal law does not require that other non-federal employees be paid. These federal holidays are based significant cultural and historical events. The US federal holidays are: New Year's Day (January 1), Martin Luther King Jr.'s Birthday (a Monday in February), Washington's Birthday (a Monday in February), Memorial Day (a Monday in May), Independence Day (July 4), Columbus Day (a Monday in October), Thanksgiving Day (a Thursday in November), and Christmas Day (December 25).

The requirement of mandated paid holidays in China and Russia is an example of equality-based fairness in employment laws because all employees receive the same holidays.

Vacations: In addition to these specific holidays, both China and Russia. Require that employees receive time off from work with pay for vacations. The schedule of the vacation days is not predetermined but generally is up to the agreement of the employee and employer. The US does not require paid vacation days, but most employers do provide them.

In Russia, all employees receive 28 days of paid vacation per year, regardless of how long they have worked for their employer, although employers can provide a higher number of vacation days (IBP, 2016).

In China, labor laws provide that employees receive at least a minimum amount of paid vacation days based on the number of years that they have 
worked for their employer, although employers can provide a higher number of paid vacation days. Employees with more than 1 and less than 10 years of service receive 5 paid days of vacation, employees with more than 10 and less than 20 years receive 10 days, and employees with more than 20 years of service receive 15 days (Yang, 2017).

The requirement of 28 paid vacation days in Russia is an example of equality-based fairness. All employees receive a guarantee of the same minimum number of days of vacation. The requirement of increasing the number of paid vacation days based on years of service in China is an equity-based example of fairness. Employees who have worked for more years have earned more vacation days.

Written Contract. China and Russia require that the employment relationship is formalized in a written document that is signed by the employee and the employer (Brown, 2010; Filipova, 2016; Remington \& Cui, 2015; Yang, 2017).

The US does not require a written employment contract. However, in some situations such as for top executives, professional athletes, sales executives, etc. it is more common to see a written employment contract in the US.

The requirement for a written contract in China and Russia can be seen partly as a result of two principles of fairness: equality and need. Since both China and Russia mandate that all employees have a written contract, and that all employment contracts must contain certain minimum guarantees, the requirement of a written contract supports the goal of guaranteeing that all employment relationships have at least some equal level of standards. Therefore, the written contract is an equality-based example of fairness. Also, since China and Russia require that workers be protected by the provisions of a written contract, the needs of the employees are being met. Individual employees will have a written contract to meet their needs because the federal law requires that there be written contracts. Therefore, the written contract requirement is a need-based example of fairness.

\subsection{Differences in Protections for Employers}

There are not very many differences across the countries in the protections provided for employers. Yet, this article highlights one of the most important.

Non-Compete Agreements. Non-compete agreements are legally enforceable promises that would prohibit an employee to resign and go to work for their employer's competitor. These agreements are sometimes regulated by labor laws of different countries. These agreements are also used to prohibit employees from taking the knowledge that they have gained from working at the first employer, e.g., data, customer lists, proprietary and confidential processes, methods of performing their operations, etc., and revealing that information to a subsequent employer.

In China the law permits an employee to enter into an agreement to not go to work for a competitor for up to 2 years, so long as the employer compensates the 
employee for this non-compete agreement (Yang, 2017). However, these agreements are generally only enforceable for senior managers and if the geographic scope of the agreement is reasonable. In addition, the agreement may require the employee to pay damages to the employer if they breach the agreement. Non-compete agreements are not generally allowed in Russia (Daurbekov, 2018; Ministry of Labor and Social Security of the Russian Federation, 2017). In the US there is no statutory provision at the federal level that prohibits non-compete agreements, but state laws and court decisions generally limit the time, nature, and geographic reach of enforceable non-compete agreements.

The enforceability of non-compete agreements in China and the US could be seen as an example of the equity-based principle of fairness. An employer has provided the employee with useful knowledge and information while working for them. Thus, the employer has a certain equitable interest in protecting their intellectual property from the loss to competitors.

\subsection{Comparisons of Differences across Countries}

This comparison of labor laws has shown many differences across countries. Thus, despite the pressures to adopt similar protections that may derive from mimetic isomorphism and generally accepted principles of fairness do not account for all the provisions of labor laws in different countries.

For example, while all 3 countries do provide that certain specific days should be recognized as holidays, the specifics vary greatly across countries. Thus, it can be said that the designation of special days as holidays remains an example of the equality-based principle of fairness, being the same for all employees; but the standard by which equality can be perceived applies within countries, not across countries.

Also, when it comes to paid vacations, all 3 countries allow employees to take time off from work with pay. However, only China and Russia make this a general legal requirement. Although it could be argued that the equity-based principle of fairness is the primary driver of labor law provisions for vacations, because those who have worked more years for their employer earn more vacation in China. However, in Russia all employees receive 28 days of vacation. This seems more like an equality-based example of fairness since everybody is treated equally.

However, an alternative rationale for providing paid vacations is the need-based rationale for fairness. The needs-based rationale would posit that employees need some time off from work, i.e., they can't work all year around. It would seem that employees in different country all have the same need to take some time off from work. Therefore, while the needs-based principle of fairness does support why labor laws would require paid vacations, only China and Russia have made this a nationally consistent requirement. In addition, the needs-based rationale does not explain why employees in China earn more vacation by working more years, but in Russia everyone gets at least 28 days. Do employees in Russia 
need more vacation, or is it more likely that the law makers in their country have decided as a matter of policy to provide these for workers? More in-depth research could further explore questions like this.

Similarly, both China and Russia have a requirement that employment contracts be in writing, whereas the US does not. This suggests that China and Russia may be more likely to use need and equality motivations as the rationale for their requirements for written contracts.

By contrast, there are significant differences across countries in the federal laws regarding non-compete agreements. While China permits the enforceability of non-compete agreements, Russia generally does not, and the US does not have any federal law that requires or prohibits them. While equity may be the basis for the enforceability of non-compete agreements in China, it could be argued that Russia prefers to take a more needs-based view by not allowing them.

\section{Findings and Analysis}

This study showed that there are several principles that help to explain the similarities and differences in labor laws across countries. The countries studied here all had similar structural foundations and similar sources of their labor laws. Nevertheless, it can be seen that the labor laws in each country are designed to provide a framework that reconciles the power imbalances between employees and their employers.

Yet, most labor laws provide greater protections for workers than they do for employers. This is likely to be the case since there is more often an asymmetrical power imbalance that favors employers. Thus, it is not surprising that most labor laws seem to be designed to meet the fairness perspectives of equality, equity, and need from the perspective of employees.

Moreover, another factor may account for differences between these three countries. The laws analyzed in this study seem to show that employees in China and Russia seem to have greater protections and benefits in their labor laws than do their employers. In contrast, the US seems, in general, to have taken a different approach.

The US seems to more often take a lassez-faire approach in several areas. This means that the labor laws tend to allow the relationships between employers to be allowed to follow their own path, without restrictions from federal labor laws. These areas include the following. The US does not generally require employers to pay for overtime for hours worked over 8 per day. The US does not require paid holidays or paid vacations, or a written employment contract for all workers. Nevertheless, employees covered by collective bargaining agreements and some state laws do have these benefits.

It should be noted that several commentators have argued that there are differences between the formally adopted provisions of labor laws and the actual implementation of those laws. This question has been raised in all 3 countries (Gonzalez, Sharma, \& Subhash, 2016; Piper, 2016). An interesting question for 
future research would be an unbiased comparison of the actual implementation of the protections and benefits of the labor laws across countries for both employees and employers. For example, it would be interesting to examine whether a system with more specificity, or a more lassez-faire system is more effective in achieving the intended outcomes of the labor laws in each country.

\section{Conclusion}

This article compared labor laws in 3 important countries with major economies, as well as sophisticated and dynamic legal systems: China, Russia, the US. It was shown how mimetic isomorphic tendencies may have induced each country to copy the laws of other countries. Moreover, generalizable principles of fairness can be used to explain why certain laws exist in each country. These principles include equality or equal treatment, equity based on something that was earned, and needs of workers to be protected. Both similar and distinct labor laws in China, Russia, and the US may have resulted from the perceived needs for equality, equity, and/or needs of employees in each country. Thus, a driving force behind the mimetic isomorphism that resulted in similar labor laws may be explained by the generally universal values of fairness embodied in the equality, equity, and need model of justice (Rawls, 1971).

However, the laws in these different countries continue to have unique characteristics with differing protections for both employees and employers. The unique cultural, social, and historical conditions could also explain differences in labor laws across countries.

Nevertheless, understanding these similarities and differences is important for both policy makers and business leaders. This overview of labor laws provides insights that could suggest to policy makers which laws they could adopt or what changes they could make to their laws based on their understanding of laws that have been successfully adopted in other countries. It could also suggest to business leaders what benefits they could provide to their workers that go beyond legal requirements in their own country, that have been codified in the laws in other countries.

\section{Conflicts of Interest}

The author declares no conflicts of interest regarding the publication of this paper.

\section{References}

Addati, L., Cassirer, N., \& Gilchrist, K. (2014). Maternity and Paternity at Work: Law and Practice across the World (p. 138). Geneva: International Labour Organization.

Bliss, A. J. (1997). Comment: Proletariat to Perestroika: A Comparison of Labor Law in the Soviet Union and the Russian Federation. Comparative Labor Law \& Policy Journal, 18, 264-269.

Boguen, A. (2019). Understanding China Employment and Labor Law. Shanghai: New Horizons Global Partners. https://nhglobalpartners.com/china-employment-law 
Brown, D. (2019). Apple Denies It Violated Labor Laws in China; Report Alleges Harsh Working Conditions. USA Today.

https://advance.lexis.com/api/document?collection=news\&id=urn:contentItem:5X15-K 1K1-DYRR-94X1-00000-00\&context=1516831

Brown, R. C. (2010). Understanding Labor and Employment Law in China. Cambridge: Cambridge University Press. https://doi.org/10.1017/CBO9780511642258

Brown, R. C. (2012). East Asian Labor and Employment Law: International and Comparative Context. Cambridge: Cambridge University Press. https://doi.org/10.1017/CBO9781139087629

Cheng, H., Flores, G., Singh, S., \& Posthuma, R. (2018). Employment Discrimination Laws: A Country Level Analysis of Voice and Accountability. International Journal of Law and Management, 60, 1286-1298. https://doi.org/10.1108/IJLMA-06-2017-0129

Cooney, S., Gahan, P., \& Mitchell, R. (2011). Legal Origins, Labour Law and the Regulation of Employment Relations. In Research Handbook of Comparative Employment Relations (pp. 75-97). Cheltenham: Edward Elgar.

https://doi.org/10.4337/9780857936318.00010

Daurbekov, A. (2018). Agreement of Non-Competition in the Labor Law of China. Sociopolitical Sciences, 3, 127-130.

Deak, L. (1995). Customary International Labor Laws and Their Application in Russia. Tulsa Journal of Comparative \& International Law, 2, 319.

Demidov, N. V. (2019). Criteria for the Formation of the Labour-Law Branch in Russia. Russian Juridical Journal, 128, 118-131.

Dimaggio, P. J., \& Powell, W. W. (1983). The Iron Cage Revisited: Institutional Isomorphism and Collective Rationality in Organizational Fields. American Sociological Review, 48, 147-160. https://doi.org/10.2307/2095101

Dowling Jr., D. C. (2001). The Practice of International Labor \& Employment Law: Escort Your Labor/Employment Clients into the Global Millennium. The Labor Lawyer, 17, $1-23$.

Filipova, I. (2016). An Employment Contract: The Concept, Form, and Contact, an Example of Russian, French, UK, US, and Chinese Legislation. Russian Juridical Journal, 108, 187-194.

Franceschini, I. (2020). Hegemonic Transformation: The State, Laws, and Labour Relations in Post-Socialist China. China Journal, 81, 172-174. https://doi.org/10.1086/700369

Garcia, M. F., Posthuma, R. A., \& Quiñones, M. (2010). How Benefit Information and Demographics Influence Employee Recruiting in Mexico. Journal of Business and Psychology, 25, 523-531. https://doi.org/10.1007/s10869-010-9175-4

Gerasimova, E., Korshunova, T., \& Chernyava, D. (2017). New Russian Legislation on Employment of Teleworkers: Comparative Assessment and Implications for Future Development. Pravo. Zhurnal Vyssheyshkoly Ekonomiki, No. 2, 116-129. https://doi.org/10.17323/2072-8166.2017.2.116.129

Gonzalez, A., Sharma, S., \& Subhash, H. (2016). Enforcement Capacity and the Impact of Labor Regulation: Evidence from the Russian Federation. Washington DC: The World Bank. https://doi.org/10.1596/1813-9450-7888

Harper, V. E. (2009). The 60th Anniversary of the PRC; a Retrospective on the Chinese Legal System: From Contracts to Compliance? An Early Look at Implementation under China's New Labor Legislation. Columbia Journal of Asian Law, 23, 35.

International Business Publications (IBP) (2016). Russian Business Law Handbook Vol. 
16 Labor Laws and Regulations.

Isaacs, J., Lu, Z., \& An, B. (2019). China Employment Law Update. https://globalcompliancenews.com/china-employment-law-update-june-2019-20190704

Jia, N., Dong, X., \& Song, Y. P. (2018). Paid Maternity Leave and Breastfeeding in Urban China. Feminist Economics, 24, 31-53. https://doi.org/10.1080/13545701.2017.1380309

Jing, L. (2009). China's New Labor Contract Law and Protection for Workers. Fordham International Law Journal, 32, 1083.

Lee, S., McCann, D., \& Messenger, J. C. (2007). Working Time around the World: Trends in Working Hours, Laws, and Policies in a Global Comparative Perspective. Abingdon-on-Thames: Routledge.

Mahy, P., Mitchell, R., Sutherland, C. et al. (2019). Measuring Worker Protection Using Leximetrics: Illustrating a New Approach in Four Asia-Pacific Countries. American Journal of Comparative Law, 67, 515-549. https://doi.org/10.1093/ajcl/avz024

Ministry of Labor and Social Security of the Russian Federation (2017). Letter No. 14-2/B-942.

https://www.borenius.ru/en/2017/11/ministry-labour-on-non-compete-clauses

Piper, D. L. A. (2016). China Ministry of Human Resources Issues Three New Regulations to Strengthen Enforcement of Labor Laws in 2017.

https://www.lexology.com/library/detail.aspx?g=9f8c2e5d-91f8-4171-b584-7804afc1dd $\underline{\mathrm{c} 4}$

Posthuma, R. A. (2012). Will Your Workers Sue You? State-by-State Risks and Strategic Responses. Business Horizons, 55, 65-79. https://doi.org/10.1016/j.bushor.2011.09.004

Posthuma, R. A., Dworkin, J. B., Torres, V., \& Bustillos, D. (2000). Labor and Employment Laws in Mexico and the US: An International Comparison. Labor Law Journal, 51, 95-111.

Posthuma, R. A., Flores, G. L., Dworkin, J. B., \& Pavel, S. (2016). Social Context and Employment Lawsuit Dispute Resolution. International Journal of Conflict Management, 27, 547-569. https://doi.org/10.1108/IJCMA-10-2015-0072

Posthuma, A., \& Ebert, F. (2011). Labour Provisions in Trade Arrangements: Current Trends and Perspectives (p. 205). International Institute for Labour Studies Discussion Paper.

Posthuma, R. A., Roehling, M. V., \& Campion, M. A. (2006). Applying US Employment Discrimination Laws to International Employers: Advice for Scientists and Practitioners. Personnel Psychology, 59, 705-739. https://doi.org/10.1111/j.1744-6570.2006.00051.x

Pull, K. (2002). The Comparative Attractiveness of International Business Locations: The Role of Labor Law. Management Decision, 40, 647-654. https://doi.org/10.1108/00251740210438472

Rawls, J. (1971). A Theory of Justice. Cambridge, MA: Harvard University Press.

Remington, T. F., \& Cui, X. W. (2015). The Impact of the 2008 Labor Contract Law on Labor Disputes in China. Journal of East Asian Studies, 15, 271-299. https://doi.org/10.1017/S1598240800009371

Roehling, M. V., Posthuma, R. A., \& Hickox, S. (2008). Foundations for Understanding the Legal Environment of HRM in a Global Context. In The Routledge Companion to Strategic Human Resource Management (pp. 87-105). Abingdon-on-Thames: Routledge. https://doi.org/10.4324/9780203889015.pt3

Sychenko, E. (2019). The Development of Russian Labor Law. Eastern Europe \& Central Asia, 8, 75-82. https://doi.org/10.1353/reg.2019.0003 
Tiefenbrun, S. (2017). China's Employment Laws and Their Impact on Women Working in China. U.C. Davis Journal of International Law \& Policy, 23, 253.

Torres, R. (2013). World of Work Report 2013: Repairing the Economic and Social Fabric. Geneva: International Labour Organisation, International Institute for Labour Studies. https://doi.org/10.1002/wow3.34

Wang, J. T. (2009). Comment: Article 14 of China's New Labor Contract Law: Using Open-Term Contracts to Appropriately Balance Worker Protection and Employer Flexibility. Pacific Rim Law \& Policy Journal, 18, 433.

Yang, G. (2017). The China Employment Law Guide. Seattle, Washington DC: TCK Publishing. 